\title{
The effect of feeding high levels of low-quality proteins to growing chickens
}

\author{
BY E. WE'THLI, T. R. MORRIS ANd T. P. SHRESTA \\ Department of Agriculture and Horticulture, University of Reading, \\ Earley Gate, Reading $R G 62 A T$
}

(Received 26 July 1974-Accepted 2 September 1974)

\begin{abstract}
I. Three growth trials were done using male broiler chicks. In the first two trials, groundnut meal was used, with and without supplementary methionine and lysine. In the third trial, soya-bean meal was used with and without supplementary methionine. Protein levels ranged in the first trial from 120 to $420 \mathrm{~g} / \mathrm{kg}$ diet and in the third trial from 120 to $300 \mathrm{~g} / \mathrm{kg}$ diet. Thus the assumed minimal amino acid requirements of the chick were supplied by high levels of low-quality dietary protein.

2. Diets based on cereals and groundnut meal did not support maximum live-weight gain or maximum efficiency of food utilization at any level of dietary protein. When the principal deficiencies of lysine and methionine were corrected, this protein mixture was capable of supporting the same growth rate as a control diet of cereals and herring meal.

3. Diets based on maize and soya-bean meal did not support quite the same growth rate as similar diets supplemented with methionine, even though the protein level in the unsupplemented diets was sufficient to meet the assumed methionine requirements.

4. These results are interpreted as examples of amino acid imbalance in diets composed of familiar feeding-stuffs. It is concluded that one cannot assume that the poor quality of a protein source can always be offset by increasing the concentration of dietary protein.
\end{abstract}

Many reports deal with the problem of defining and measuring protein quality (e.g. Porter \& Rolls, I973) but less has been written about the incorporation of lowquality proteins into diets which satisfy the requirements for rapid growth. All measures of protein quality seek, directly or indirectly, to provide an index of the rate at which an animal synthesizes protein when given a diet with a specified (and limiting) concentration of protein. Such tests do not answer the important questions: (I) is it possible to achieve the maximum rate of protein synthesis of which the animal is capable merely by increasing the concentration of test protein in the diet; (2) if so, what concentration of dietary protein is needed to support maximum protein synthesis? In principle, slope-ratio assays, which form the basis of most protein-quality tests, are capable of predicting the answer to the second question, but only if $(a)$ rectilinear responses are assumed to continue up to maximum performance, $(b)$ the level of maximum performance is known, $(c)$ the actual slopes (as distinct from the relative slopes) are reported.

Carpenter \& de Muelenaere (1965) discussed these problems and reported evidence suggesting that chicks given a diet with a high level of protein supplied by groundnut flour (with supplementary lysine) grew as well as chicks given either a balanced diet or a lower level of groundnut protein supplemented with methionine as well as lysine. 'They did not report whether normal growth could be obtained from a high-protein groundnut diet without lysine supplementation. Subsequent papers by Carpenter $\&$ Anantharaman (1968) and Anantharaman, Carpenter \& Nesheim (1968), although 
dealing with the value of poor-quality proteins given at high levels, were more concerned with the efficiency of protein utilization and the invalidity of the equations of Miller \& Payne ( 1963 ) than with the direct question whether high levels of poorquality proteins can support normal growth.

Negassi \& Morris (1973) reported that a diet containing a high level of niger oilseed meal did not satisfy the chick's requirement for rapid growth, although excellent growth was obtained when the same diet, or a lower-protein diet, was supplemented with the first and second limiting amino acids. This was an instance in which amino acid imbalance prevented maximum output being obtained from a diet formulated on the basis that it was the cheapest and most suitable practical diet for feeding to young chicks in Ethiopia.

There seems to be no corresponding evidence to indicate whether maximum growth rate can be obtained using high levels of groundnut meal, without lysine or methionine supplementation, or high levels of soya-bean meal without methionine supplementation. Since these two protein sources are important in the total world economy, it is worth seeking better evidence about this aspect of their use in diets designed for animal or human feeding. This paper reports experiments in which high levels of groundnut or soya-bean meals were fed to growing chicks.

\section{EXPERIMENTAL}

\section{Animals and facilities}

Three experiments were done using fast-growing male chicks (Ross I; Ross Poultry Ltd, Rose Lane, Norwich NRI IPU). The birds were housed at I d of age in four electrically-heated tiered brooders. Each brooder had eight compartments arranged on four levels, and sixteen or seventeen chicks were allocated to each compartment. Food and water were provided $a d$ lib. Chicks and food were weighed at weekly intervals and the mean weights of groups were used to estimate treatment responses and error variances.

\section{Plan of experiments}

Expt I. The first experiment was designed to compare responses to increasing concentrations of protein in diets using herring meal or groundnut meal or groundnut meal with supplementary methionine and lysine as the principal sources of protein (' $H$ ', ' $G$ ' and 'GIm' series of diets respectively). Cereals were used as the basis of the diets, since this imitates the situation in which the high-protein materials would normally be used, but the principal diets were designed so that the protein composition did not vary as dietary protein level was varied. Details of treatments are given in Table $\mathbf{I}$ and details of dietary composition are given in Table 2.

It was calculated from the values listed in Table 3 that, using groundnut meal, wheat and barley as the protein sources, a protein level of $360 \mathrm{~g} / \mathrm{kg}$ (diet $\mathrm{G}_{3} 6$ ) would meet all the amino acid requirements of the chick (as given by Hewitt \& Lewis (1972)) except for methionine which would be slightly below requirement. Diet $\mathrm{G}_{42}$ was included to allow for uncertainties in the tabulated requirements and foodstuff composition values. By adding synthetic methionine and lysine to the groundnut diets the 
Table I. Protein sources and treatments given to chicks in Expts $\mathrm{I}$ and 2

\begin{tabular}{|c|c|c|c|c|c|}
\hline \multirow{3}{*}{$\begin{array}{l}\text { Dietary } \\
\text { protein level } \\
\quad(\mathrm{g} / \mathrm{kg})\end{array}$} & \multicolumn{5}{|c|}{ Protein sources } \\
\hline & \multirow{2}{*}{$\begin{array}{l}\text { Cereal- } \\
\text { groundnut } \\
\text { meal (G) } \\
\text { Expt I }\end{array}$} & \multicolumn{2}{|c|}{$\begin{array}{c}\text { Cereal-groundnut } \\
\text { meal plus lysine } \\
\text { and methionine }(\mathrm{Glm})\end{array}$} & \multicolumn{2}{|c|}{$\begin{array}{c}\text { Cereal-herring } \\
\text { meal }(\mathrm{H})\end{array}$} \\
\hline & & Expt I & Expt 2 & Expt I & Expt 2 \\
\hline 120 & $\mathrm{G}_{12}$ & Glmi2 & 一 & $\mathrm{H}_{12}$ & - \\
\hline 150 & - & - & - & - & $\mathrm{H}_{15}$ \\
\hline 180 & $\mathrm{Gr} 8$ & Glmi 8 & Glm1 8 & $\mathrm{H}_{1} 8$ & Hr8 \\
\hline 210 & - & - & Glm2I & $\mathrm{H}_{2 \mathrm{I}}$ & $\mathrm{H}_{2 \mathbf{I}}$ \\
\hline 240 & $\mathrm{G}_{24}$ & Glm24 & Glm24 & $\mathrm{H}_{24}$ & $\mathrm{H}_{24}$ \\
\hline 270 & - & Glm27 & Glm27 & - & - \\
\hline 300 & $\mathrm{G}_{30}$ & - & - & - & - \\
\hline 360 & $\mathrm{G}_{36}$ & - & - & $\ldots$ & - \\
\hline 420 & $\mathrm{G}_{42}$ & $\operatorname{Glm}_{42}$ & - & $\mathrm{H}_{42}$ & - \\
\hline
\end{tabular}

requirements of the chick could be met at $240 \mathrm{~g}$ protein $/ \mathrm{kg}$ (diet Glm24). Diet Glm27 was introduced to allow a margin for uncertainty and diet Glm42 was included to test whether the very high level of groundnut meal included in diet $\mathrm{G}_{42}(79 \circ \mathrm{g} / \mathrm{kg})$ was itself toxic. The groundnut meal used in the experiment was analysed for aflatoxin content by courtesy of BOCM-Silcock Ltd, Basing View, Basingstoke, Hants, and was reported to contain less than $0.5 \mathrm{mg} / \mathrm{kg}$. Using herring meal as the protein supplement, the chick's estimated requirements could be satisfied by $210 \mathrm{~g}$ protein $/ \mathrm{kg}$ (diet $\mathrm{H}_{2} \mathrm{I}$ ). Diet $\mathrm{H}_{24}$ was included to allow a margin for uncertainty and diet $\mathrm{H}_{42}$ was added to check that a high dietary protein level was not necessarily incompatible with rapid growth.

Diet $\mathrm{G}_{3} 6$ was formulated first. The composition of diet $\mathrm{G}_{12}$ was then obtained by adding maize oil, maize starch, glucose and oat hulls at the expense of cereals and groundnut meal to provide an isoenergetic diet containing $120 \mathrm{~g}$ protein $/ \mathrm{kg}$. Cereals and groundnut meal were displaced in equal proportions so that the amino acid composition of the protein remained the same throughout the ' $G$ ' series of diets. Large batches of diets $G_{12}$ and $G_{3} 6$ were prepared and diets $G_{1} 8, G_{24}$ and $G_{3}$ o were obtained by blending the appropriate proportions of diets $\mathrm{G}_{2} 2$ and $\mathrm{G}_{3} 6$ together. Diet $\mathrm{G}_{42}$ was formulated by increasing groundnut meal at the expense of cereals and so did not have the same amino acid composition as the other groundnut diets. Diets Glmi2, Glmi8, Glm21, Glm24 and Glm27 were obtained by blending together appropriate amounts of $\mathrm{G}_{12}$ and $\mathrm{G}_{3} 6$ and adding L-lysine $\mathrm{HCl}$ and DL-methionine. The levels of the third and fourth limiting amino acids (threonine and cystine) in diet Glm27 were estimated to be $1 \cdot 25$ times the chick's requirement and it was calculated that the addition of $2 \cdot 3^{2} \mathrm{~g}$ methionine and $2 \cdot 18 \mathrm{~g}$ lysine $\mathrm{HCl} / \mathrm{kg}$ diet would bring the levels of these amino acids to $1 \cdot 25$ times requirement also. Amino acid additions to the other diets in the 'Glm' series were in corresponding proportion to their protein contents.

Diet $\mathrm{H}_{12}$ was formulated by diluting diet $\mathrm{H}_{24}$ (see Table 2) and diets $\mathrm{H}_{1} 8$ and $\mathrm{H}_{2} \mathrm{r}$ were made by blending diets $\mathrm{H}_{12}$ and $\mathrm{H}_{24}$ together. The high-protein control diet 


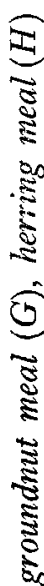

总

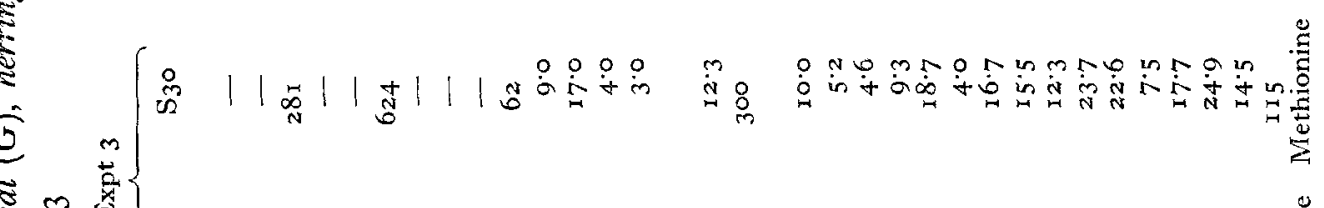

कृ

उ.

[ 素

至

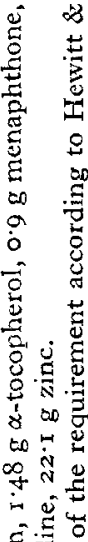

要

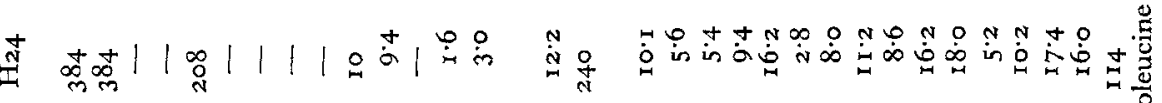

N 要总

कि

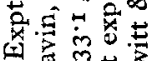

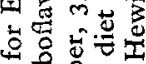

式

要

$+\stackrel{\infty}{\text { in }} \subseteq$

垔

:

b.

$\because 5$

$\sum_{2}^{2}$

ह 3

ปี

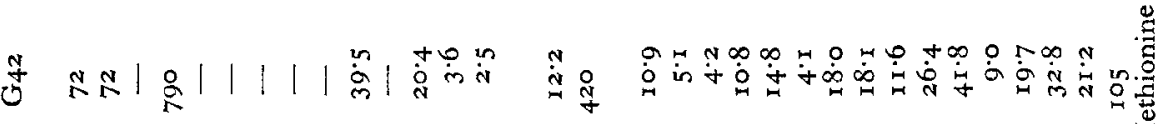

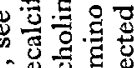

H U

金㐁

留 on

马े घ.

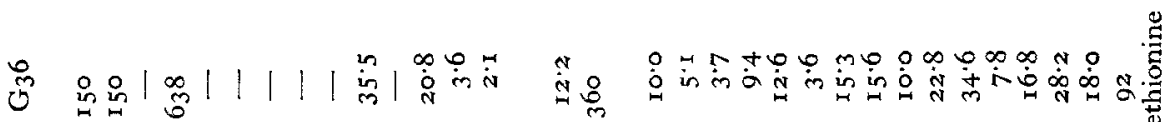

in

훙.

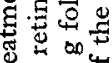

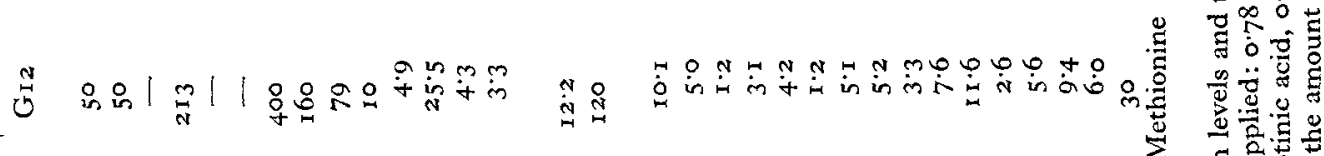

昰高

ב.

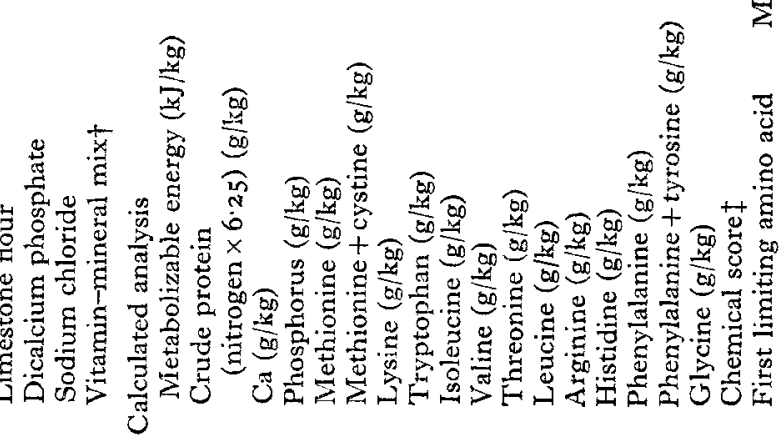

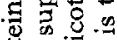

蕺.

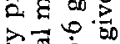

远

总承总 
Table 3. Assumed metabolizable energy ( $k f / k g)$ and crude protein and amino acid contents $(\mathrm{g} / \mathrm{kg})$ of the protein sources used in diets given to chicks

\begin{tabular}{|c|c|c|c|c|c|c|}
\hline & $\begin{array}{c}\text { Ground } \\
\text { maize }\end{array}$ & $\begin{array}{c}\text { Ground } \\
\text { wheat }\end{array}$ & $\begin{array}{c}\text { Ground } \\
\text { barley }\end{array}$ & $\begin{array}{c}\text { Ground- } \\
\text { nut } \\
\text { meal }\end{array}$ & $\begin{array}{c}\text { Herring } \\
\text { meal }\end{array}$ & $\begin{array}{c}\text { Soya- } \\
\text { bean } \\
\text { meal }\end{array}$ \\
\hline Metabolizable energy & $14 \%$ & I 2.9 & $\mathrm{II} \cdot 4$ & I I 5 & $12 \cdot 6$ & $9 \cdot 6$ \\
\hline Crude protein (nitrogen $\times 6.25$ ) & 90 & 120 & II0 & 510 & 720 & 440 \\
\hline Methionine & $\mathrm{I} \cdot 8$ & $\mathbf{1} \cdot 7$ & $I \cdot 6$ & $5 \cdot 0$ & $20 \cdot 0$ & 6 \\
\hline Methionine + cystine & $3 \cdot 6$ & $3 \cdot 7$ & $3 \cdot 6$ & $13 \cdot 0$ & $32 \cdot 0$ & I 3. \\
\hline Lysine & $2 \cdot 0$ & $3 \cdot 5$ & 4.0 & $18 \cdot 0$ & $64 \cdot 0$ & 29 \\
\hline Tryptophan & $I \cdot O$ & $\mathbf{I} \cdot 0$ & $I \cdot 5$ & $5 \cdot \circ$ & $9 \cdot 0$ & 6 \\
\hline Isoleucine & $4 \cdot 0$ & $5 \cdot 0$ & $4^{\circ}$ & $22 \cdot 0$ & $37^{\circ} 0$ & \\
\hline Valine & $4^{\circ} \cdot$ & $5 \cdot 0$ & $5 \cdot 2$ & $22: 0$ & $35^{\circ} 0$ & 23 \\
\hline Threonine & 3.7 & $3 \cdot 6$ & $3 \cdot 5$ & $14 \cdot 0$ & $28 \cdot 0$ & \\
\hline Leucine & II $\cdot 0$ & $8 \cdot 0$ & $7 \cdot 0$ & $32 \cdot 0$ & $50 \cdot 0$ & 33 \\
\hline Arginine & $4 \cdot 3$ & $4 \cdot 8$ & $5 \cdot 0$ & $52 \cdot 0$ & $68 \cdot 0$ & 34 \\
\hline Histidine & $2 \cdot 3$ & $2 \cdot 4$ & $2 \cdot 3$ & II $\cdot 0$ & $16 \cdot 0$ & I I \\
\hline Phenylalanine & $5^{\circ} \mathrm{O}$ & $5 \cdot 0$ & $5 \cdot 5$ & $24 \cdot 0$ & $30 \cdot 0$ & 26 \\
\hline Phenylalanine + tyrosine & $8 \cdot 2$ & $9 \cdot 0$ & $8 \cdot 5$ & $40 \cdot 0$ & $52 \cdot 0$ & \\
\hline Glycine & $5 \cdot 0$ & 6.0 & $3 \cdot 5$ & $26 \cdot 0$ & $59 \cdot 0$ & \\
\hline
\end{tabular}

$\left(\mathrm{H}_{42}\right)$ was prepared by using the maximum amount of herring meal, without exceeding an upper limit for phosphorus, and then adding soya-bean meal to make up the protein; the proportion of herring meal in diet $\mathrm{H}_{42}$ was less than that in diet $\mathrm{H}_{24}$.

Two groups, each of sixteen or seventeen chicks, were allocated in a randomized block design to each of the sixteen diets at $7 \mathrm{~d}$ of age. Experimental diets were given from 7 to $2 \mathrm{I} d$ of age. From $\mathrm{I}$ to $7 \mathrm{~d}$ of age all chicks were fed on a diet containing $200 \mathrm{~g}$ groundnut meal and $54 \mathrm{~g}$ herring meal/kg diet and calculated to contain $220 \mathrm{~g}$ protein/kg.

Expt 2. This was a trial designed to clear up some doubts which were left by Expt $\mathrm{I}$. Eight diets were used with four groups, each of sixteen or seventeen chicks, allocated to each diet. Treatments were arranged at random in four blocks, with each brooder forming one block, but with the added constraint that each treatment appeared only once in each tier.

The treatments were four levels of protein supplied by cereals, groundnut meal and supplementary methionine and lysine, and four levels of protein supplied by cereals and herring meal (see Table $\mathrm{I}$ ). Diets were prepared in the same way as the ' $\mathrm{Glm}$ ' series and the ' $H$ ' series in Expt I (see Table 2). The same sample of groundnut meal was used but other foodstuffs were drawn from fresh consignments.

The same 'starter' diet was used as in Expt $\mathrm{I}$ and the treatments were given from 7 to $28 \mathrm{~d}$ of age.

Expt 3. In this trial soya-bean meal was tested with and without methionine supplementation (' $\mathrm{S}$ ' and ' $\mathrm{Sm}$ ' series of diets respectively). Maize was used as the cereal base because it is the common cereal in areas where soya beans are grown for oil extraction. A high-protein diet was formulated ( $\mathrm{S}_{3} \mathrm{O}$ in Table 2 ) and five lower protein levels $(270,240,210,180$ and I $20 \mathrm{~g}$ protein $/ \mathrm{kg}$ ) were obtained by dilution with protein-free materials. The composition of the lowest-protein diet $\left(\mathrm{S}_{12}\right)$ is given in Table 2 and those of intermediate diets can be deduced by linear interpolation. A 
Table 4. Expt I. Mean live weights and food consumption of chicks given, from 7 to 2 I $d$ of age, diets containing cereals and groundnut meal $(G)$, groundnut meal with supplementary methionine and lysine $(G l m)$ or herring meal $(H)$ as the principal sources of protein

\begin{tabular}{|c|c|c|c|c|c|}
\hline \multirow[t]{2}{*}{ Diet* } & \multicolumn{2}{|c|}{$\begin{array}{c}\text { Mean live wt } \\
\text { (g) }\end{array}$} & \multirow{2}{*}{$\begin{array}{l}\text { Mean food } \\
\text { intake } \\
\text { (g/chick) } \\
(7-2 \text { I d })\end{array}$} & \multirow{2}{*}{$\begin{array}{l}\text { Food conversion efficiency } \\
\text { (g wt gain/g food intake) } \\
(7-2 \mathrm{~d})\end{array}$} & \multirow{2}{*}{$\begin{array}{l}\text { Net proteir } \\
\text { intakef }(\mathrm{g}) \\
\left(7^{-2} \mathrm{I} \mathrm{d}\right)\end{array}$} \\
\hline & $14 \mathrm{~d}$ & $2 \mathrm{Id}$ & & & \\
\hline $\mathrm{G}_{12}$ & 104 & 130 & 245 & 0.204 & 8.8 \\
\hline Gi 8 & 127 & 190 & 345 & 0.316 & 27.9 \\
\hline $\mathrm{G}_{24}$ & $x 46$ & 258 & 401 & 0.445 & $58 \cdot 7$ \\
\hline $\mathrm{G}_{30}$ & I65 & 308 & $44^{6}$ & 0.506 & IOI 7 \\
\hline $\mathrm{G}_{36}$ & 180 & 354 & $45^{8}$ & 0.594 & $151 \cdot 7$ \\
\hline $\mathrm{G}_{42}$ & 169 & 335 & 459 & 0.553 & $202: 4$ \\
\hline Glmi2 & 120 & I 67 & 318 & 0.275 & $2 I \cdot 0$ \\
\hline$G \operatorname{lm} x 8$ & 152 & 272 & 455 & 0.423 & $67 \cdot 2$ \\
\hline Glm24 & 180 & $35^{2}$ & 499 & 0.552 & I $3 \mathrm{I} \cdot 8$ \\
\hline $\operatorname{Glm} 27$ & 182 & 373 & 488 & 0.597 & 1647 \\
\hline $\mathrm{Glm}_{42}$ & 196 & $3^{81}$ & 475 & 0.643 & $379^{\cdot 1}$ \\
\hline $\mathrm{H}_{12}$ & 167 & 293 & 494 & 0.421 & $33 \cdot 8$ \\
\hline $\mathrm{HI}_{1} 8$ & 190 & 359 & 531 & 0.525 & $81 \cdot 3$ \\
\hline $\mathrm{H}_{21} \mathrm{I}$ & $2 I I$ & 412 & $53^{8}$ & 0.611 & $\operatorname{II} 3 \cdot 0$ \\
\hline $\mathrm{H}_{24}$ & 195 & 362 & 491 & 0.570 & $134: 3$ \\
\hline $\mathrm{H}_{42}$ & 210 & 403 & 501 & 0.648 & $401 \cdot 9$ \\
\hline $\begin{array}{l}\text { SE of } \\
\text { means }\end{array}$ & 3.6 & $8 \cdot 5$ & $12 \cdot 3$ & 0.0114 & \\
\hline
\end{tabular}

Over-all mean live wt at $7 \mathrm{~d}$ was $80 \mathrm{~g}$.

* Two groups, each of sixteen or seventeen chicks, received each diet; for details of diets, see Tables $I$ and 2.

$+($ Total protein intake $\times$ chemical score (as given in Table 3$)) \div$ Ioo.

second series of diets ( $\left.\mathrm{SmI}_{2}-\mathrm{Sm} 3 \mathrm{O}\right)$ was obtained by adding DL-methionine at levels calculated to provide a total of $0.4 \mathrm{~g}$ methionine $/ 22 \mathrm{~g}$ protein (i.e. an addition of $0.34 \mathrm{~g}$ methionine $/ \mathrm{kg}$ diet to $S_{12}$ and $0.85 \mathrm{~g}$ methionine $/ \mathrm{kg}$ diet to $S_{3}$ ).

Each diet was given from $\mathrm{I}$ to $2 \mathrm{I} \mathrm{d}$ of age to two groups, each of sixteen or seventeen chicks, using a randomized block design.

\section{RESULTS}

The chicks grew well in all three experiments. Mortality rates during the course of the treatments were $0 \cdot 8,2 \cdot 3$ and $I \cdot 2 \%$ in Expts 1,2 and 3 respectively.

Tables 4,5 and 6 summarize values for mean live weights, food intake and efficiency of food utilization for the three experiments. 'Net protein' intakes ( $g$ protein intake/ chick $\times$ chemical score $\div 100$ ) are also given in these tables as indices of the relative intakes of the first limiting amino acid on the different diets. Fig. I summarizes the principal responses of live-weight gain to dietary protein level.

\section{Expt $\mathrm{I}$}

The protein sources ranked in the expected order, with marked differences between them in both growth rate and food conversion efficiency when protein was limiting. In the ' $G$ ' series of diets, growth improved as protein level was increased up to 
$360 \mathrm{~g} / \mathrm{kg}$. However, the maximum 21 d live weight obtained with unsupplemented groundnut protein was only $86 \%$ of the maximum reached by chicks given a lower level of protein from cereals and herring meal.

Supplementation of the groundnut meal with methionine and lysine resulted in substantial improvements in growth rate. At the two lowest protein levels ' $\mathrm{Glm}$ ' diets did not support the same growth as the ' $H$ ' series, but it was not expected that they would because the amino acid compositions of the two series of diets were not equivalent. By increasing the dietary protein level in the 'Glm' series to $270 \mathrm{~g} / \mathrm{kg}$ a performance almost equal to that with diet $\mathrm{H}_{2} \mathrm{r}$ was obtained. The difference in $2 \mathrm{I} d$ live-weight values between diets $\mathrm{H}_{21}$ and Glm27 was significant $(P<0.05)$ but the difference in efficiency of food utilization was not.

At $420 \mathrm{~g}$ protein $/ \mathrm{kg}$ both the herring meal and the supplemented groundnut diets gave good growth and excellent food conversion efficiency. Thus the failure of the unsupplemented groundnut diets to support maximum growth at any level of protein cannot be attributed to toxicity or to simple unpalatability of the groundnut meal, or to inability of the chick to deal with diets containing high levels of protein. The intakes of methionine for diets $\mathrm{G}_{3} 6$ and $\mathrm{G}_{42}$ were very substantially greater than that for diet $\mathrm{H}_{2 \mathrm{I}}$ and therefore poor growth with the groundnut diets cannot be attributed to simple deficiency of the first limiting amino acid. The presumption must be that the failure of the groundnut diets was due to the unfavourable balance of amino acids in the protein, as the simple addition of lysine and methionine restored performance almost to the maximum level.

Because the Hzr diet supported a growth rate which was significantly better than $\mathrm{H}_{24}$ and $\mathrm{Glm} 24$ and $\mathrm{Glm} 27$, but did not show a significantly better food conversion efficiency, it was thought advisable to repeat parts of the ' $\mathrm{H}$ ' and ' $\mathrm{Glm}$ ' series, with additional replication (Expt 2).

\section{Expt 2}

The chicks used for this experiment were heavier when delivered from the hatchery and at $7 \mathrm{~d}$ of age they weighed $30 \%$ more than those of Expt $\mathrm{r}$. Growth rates were therefore better throughout the trial but the pattern of responses was similar to that obtained with corresponding diets in Expt $\mathrm{I}$. Live weights were the same with diets $\mathrm{H}_{21}$ and $\mathrm{H}_{24}$ and the same live weight was obtained with diet $\mathrm{Glm}_{27}$, but food intake was significantly higher.

In Expt I food intake at all levels of protein had been higher for the ' $H$ ' series of diets than for the 'Glm' series but in Expt 2 the chicks ate more of the high-protein groundnut diets than of the high-protein herring diets. This may account for the better growth rates with the 'Glm' series of diets in Expt 2.

We may conclude that a diet based on cereals and groundnut meal and incorporating supplementary methionine and lysine is capable of supporting maximum growth rate in the baby chick, although the level of protein required will of course be greater than that needed when a high-quality protein is used. 
Table 5. Expt 2. Mean live weights and food consumption of chicks given, from 7 to $28 d$ of age, diets containing cereals and increasing amounts of groundnut meal with supplementary methionine and lysine $(G l m)$ or herring meal $(H)$ as the principal sources of protein

\begin{tabular}{|c|c|c|c|}
\hline \multirow{2}{*}{ Diet* } & \multicolumn{3}{|c|}{$\begin{array}{l}\text { Mean live wt } \\
(\mathrm{g})\end{array}$} \\
\hline & $14 \mathrm{~d}$ & $21 \mathrm{~d}$ & $28 \mathrm{~d}$ \\
\hline Glmı 8 & 209 & 358 & ${ }_{5}^{66 \mathrm{r}}$ \\
\hline GlmzI & 222 & 392 & 628 \\
\hline Glm24 & 242 & $44^{8}$ & 722 \\
\hline Glma7 & 258 & 498 & 803 \\
\hline $\mathrm{H}_{2}$ & 238 & 433 & 671 \\
\hline $\mathrm{H}+8$ & 253 & 466 & 737 \\
\hline $\mathrm{H}_{2 \mathrm{I}}$ & 262 & 502 & $79 \mathrm{I}$ \\
\hline $\mathrm{H}_{24}$ & 258 & $50 \mathrm{r}$ & 800 \\
\hline $\begin{array}{l}\mathrm{SE} \text { of } \\
\text { means }\end{array}$ & $4 \cdot 8$ & $6 \cdot 1$ & \\
\hline
\end{tabular}

\begin{tabular}{|c|c|c|}
\hline $\begin{array}{c}\text { Mean food } \\
\text { intake (g/chick) } \\
(7-28 \mathrm{~d})\end{array}$ & $\begin{array}{c}\text { efficiency } \\
(\mathrm{g} \text { wt gain/ } \\
\mathrm{g} \text { food intake }) \\
(7-28 \mathrm{~d})\end{array}$ & $\begin{array}{l}\text { Net protein } \\
\text { intaket }(\mathrm{g}) \\
(7-28 \mathrm{~d})\end{array}$ \\
\hline $105 \mathrm{I}$ & 0.428 & I $55^{\circ} \mathrm{I}$ \\
\hline I I I I & 0.465 & 224.0 \\
\hline 1200 & 0.510 & $316 \cdot 8$ \\
\hline 1216 & 0.568 & 410.4 \\
\hline 1209 & 0.463 & I 28.8 \\
\hline 1153 & 0.543 & $\mathrm{x} 76.4$ \\
\hline II 52 & $0.59 r$ & $24 \mathrm{r} \cdot 9$ \\
\hline 1 I 4.8 & 0.602 & 314.1 \\
\hline 17.8 & 0.0100 & \\
\hline
\end{tabular}

Over-all mean live wt at $7 \mathrm{~d}$ was I I $\mathrm{g}$.

* Four groups, each of sixteen or seventeen chicks, received each diet; for details of diets, see Tables $I$ and 2.

$\uparrow($ Total protein intake $\times$ chemical score (as given in Table 3$)) \div$ xoo.

Table 6. Expt 3. Mean live weights and food consumption of chicks given, from $\mathrm{I}$ to $2 \mathrm{I} d$ of age, diets containing increasing amounts of cereal and soya-bean meal $(S)$ or soya-bean meal with supplementary methionine $(\mathrm{Sm})$ as the principal sources of protein

\begin{tabular}{|c|c|c|c|}
\hline \multirow{2}{*}{ Diet* } & \multicolumn{3}{|c|}{$\begin{array}{c}\text { Mean live wt } \\
(\mathrm{g})\end{array}$} \\
\hline & $7 \mathrm{~d}$ & $14 \mathrm{~d}$ & $21 \mathrm{~d}$ \\
\hline Srz & 95 & 178 & 257 \\
\hline S18 & I 15 & 253 & 435 \\
\hline $\mathrm{S}_{21}$ & I2I & 274 & 492 \\
\hline $\mathrm{S}_{24}$ & 119 & 280 & 5 II \\
\hline S27 & I 18 & 275 & 506 \\
\hline $\mathrm{S}_{30}{ }^{\circ}$ & II 6 & 261 & 467 \\
\hline $\mathrm{SmI} 2$ & 103 & 212 & 340 \\
\hline $\operatorname{Sm} 18$ & II 7 & 269 & $47 \mathrm{I}$ \\
\hline Smzr & 127 & 292 & $53 \mathrm{I}$ \\
\hline $\mathrm{Sm} 24$ & 130 & 300 & 539 \\
\hline $\operatorname{Sm} 27$ & 122 & 281 & 512 \\
\hline $\mathrm{Sm} 30$ & II 6 & 264 & 473 \\
\hline $\mathrm{sE}$ of & & & \\
\hline
\end{tabular}

Mean food
intake (g/chick)
$(0-21 \mathrm{~d})$
594
752
754
740
706
701
712
776
806
783
698
646

Food conversion

$\begin{array}{lllll}\text { means } & 2.6 & 6.5 & 12.4 & 18.5\end{array}$

$\begin{array}{cc}\begin{array}{c}\text { efficiency } \\ \text { (g wt gain/ } \\ \text { food intake) } \\ (0-21 ~ d)\end{array} & \begin{array}{c}\text { Net protein } \\ \text { intake }+(g) \\ (0-21 ~ d)\end{array} \\ 0.369 & 32.1 \\ 0.528 & 92.1 \\ 0.603 & 126.6 \\ 0.640 & 163.4 \\ 0.663 & 196.3 \\ 0.612 & 241.8 \\ 0.425 & 47.0 \\ 0.558 & 114.6 \\ 0.612 & 160.8 \\ 0.640 & 202.9 \\ 0.680 & 230.0 \\ 0.674 & 261.6\end{array}$

* Two groups, each of sixteen or seventeen chicks, received each diet; for details of diets, see p. $3^{67}$ and Table 2.

$\uparrow($ Total protein intake $\times$ chemical score (as given in Table 3 )) $\div$ 100. 
Vol. 34

(a)
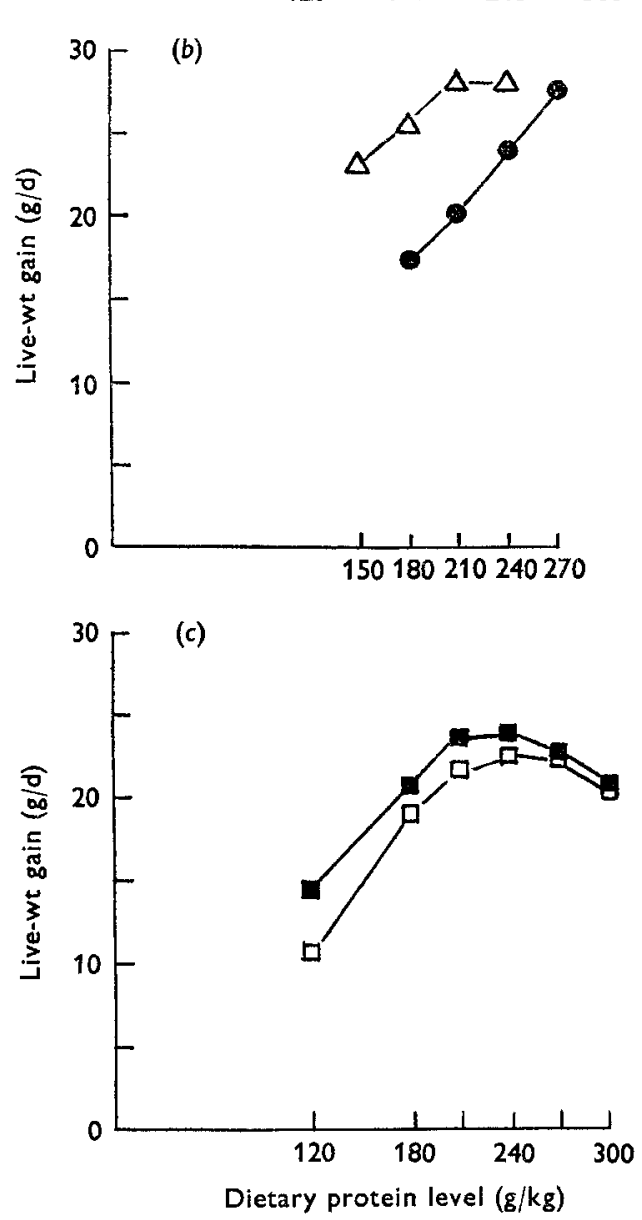

Fig. 1. Growth responses in the three experiments: (a) Expt 1, (b) Expt 2, (c) Expt 3, in which groups of chicks were given diets containing cereals and increasing amounts of $(\Delta-\Delta)$, herring meal; (A), herring meal and soya-bean meal; $(\mathrm{O}-\mathrm{O})$, groundnut meal; $(\mathbf{O}-\mathbf{O})$, groundnut meal plus methionine and lysine; ( $\square-\square$ ), soya-bean meal; (u- - ), soyabean meal plus methionine, as the principal sources of protein, from 7 to $2 \mathrm{r} d$ of age (Expt $\mathrm{r}$ ), 7 to $28 \mathrm{~d}$ of age (Expt 2) or $\circ$ to $2 \mathrm{I} \mathrm{d}$ of age (Expt 3). For details of diets and treatments, see Tables 1 and 2 and p. 365 . 


\section{Expt 3}

The chicks used for Expt 3 were not particularly large ( $39 \mathrm{~g}$ at I d of age) but their growth rate was excellent (Table 6). The addition of methionine to the maize--soyabean diets gave a growth response at all levels of dietary protein (Fig. I). The difference between diets $\mathrm{S}_{24}$ and $\mathrm{Sm} 24$, considered in isolation, was not quite significant but the pattern of responses was consistent and the mean weight of chicks given diets $\mathrm{Sm} 2 \mathrm{I}$ and $\mathrm{Sm} 24$ was about $6 \%$ greater than the mean weight of chicks given diets S2I and S24; this difference was statistically significant $(P<0.05)$. At the four lower protein levels, food intake was less with the ' $S$ ' series of diets than with the 'Sm' series of diets and good food conversion efficiencies were obtained with diets $\mathrm{S}_{2}$ I, S24 and $\mathrm{S}_{27}$. In terms of efficiency of food utilization, the unsupplemented diets given at high levels of protein were as good as the supplemented diets.

\section{DISCUSSION}

Groundnut meal and soya-bean meal are two commonly used sources of protein and it is well known that, for growing animals, soya-bean meal is deficient in methionine, and groundnut meal is deficient in both lysine and methionine. These deficiencies are not remedied by mixing the materials with cereals.

In the experiments reported here, maximum growth rate could not be obtained when groundnut meal or soya-bean meal was used as a simple supplement to a cerealbased diet, even though very high dietary protein levels were used. This failure to support maximum live-weight gain might be attributed to: (a) poor palatability; (b) a toxin or anti-nutritive factor present in the feedstuff; $(c)$ a toxic effect of high protein levels; $(d)$ an amino acid deficiency; or $(e)$ amino acid imbalance, that is, an interference with the utilization of the first limiting amino acid(s) due to the excessive levels of other amino acids. The possibility that the high-protein groundnut and soyabean diets gave poor results because they were unpalatable or toxic was removed by the finding that supplementation with the first (and, if necessary, second) limiting amino acid(s) improved growth rate at those high dietary protein levels. Deficiency of the first limiting amino acid was possible, but very unlikely. If the $\mathrm{G}_{42}$ diet contained less than the calculated $4.2 \mathrm{~g}$ methionine $/ \mathrm{kg}$, or if the chick's requirement is more than $4.0 \mathrm{~g} / \mathrm{kg}$, methionine intake might have been 'deficient'. But if that were the proper explanation one would expect continuing responses to increasing levels of groundnut meal, whereas both growth and food conversion efficiency were lower for diet $\mathrm{G}_{42}$ than for diet $\mathrm{G}_{3} 6$. Similar arguments apply to the high-protein soya-bean diets.

The only explanation which fits the evidence is that the amino acids supplied by these low-quality proteins are in such disproportion, compared with the animal's needs, that the utilization of the first limiting amino acid(s) is impaired. These results will not be surprising to those who have studied amino acid imbalance using purified diets (for review, see Harper, Benevenga \& Wohlhueter (1970)) but it has perhaps not been sufficiently appreciated that imbalance can occur in diets formulated from familiar foodstuffs. 
It should be noted that, although maximum growth rate is an important objective for a food compounder selling broiler diets in a competitive economy, it may not be an important criterion for poultry production in other parts of the world. Where groundnut meal or soya-bean meal is available and high-quality proteins and synthetic amino acids are expensive or unavailable, reasonable growth rates can be attained with all-vegetable diets. Also, compensatory growth may occur so that differences due to the type of protein supplied may not be apparent at later ages. Whether similar arguments can properly be applied to human nutrition, or whether early protein malnutrition has irreparable effects on human development, is a matter of some importance, but one that cannot be answered by experiments with chicks.

The implication of these results for those concerned with the assessment of protein quality are serious. Protein quality measurements such as gross protein value (Anwar, I960), net protein utilization (Summers \& Fisher, I96I) or total protein efficiency (Woodham, I968) place proteins in a rank order with respect to their ability to support growth when given in limiting quantities, but they do not indicate whether the materials are capable of supporting maximum growth or at what level they should be fed to achieve this. It is noticeable that the responses shown in Fig. I are mostly converging as dietary protein level is increased and not diverging as would be expected of a slope-ratio assay. This means that three-point assays of the type commonly employed to compare the relative qualities of two proteins will give false predictions about the amounts of the lower-quality protein which are needed to achieve maximum growth.

Finally, the most urgent question is how one can set rules for formulation which will ensure that diets with amino acid imbalance are not produced. D'Mello \& Lewis (1970) have published estimates of the amounts of arginine needed to offset excesses of lysine and have studied the interrelationships between leucine, isoleucine and valine. None of these antagonisms would appear to be responsible for the effects reported in the experiments above. Some system is needed which sets upper as well as lower limits for each amino acid or which specifies appropriate ratios that must be maintained. It seems that much more experimental evidence will be needed before such a system can be defined.

\section{REFERENCES}

Anantharaman, K., Carpenter, K. J. \& Nesheim, M. C. (I968). Br. F. Nutr. 22, I 99.

Anwar, A. (1960). Poult. Sci. 39, I 406.

Carpenter, K. J. \& Anantharaman, K. (1968), Br. $\mathcal{~ . ~ N u t r . ~ 2 2 , ~ I 8 3 . ~}$

Carpenter, K. J. \& de Muelenaere, H. J. H. (I 965). Proc. Nutr. Soc. 24, 202.

D’Mello, J. P. F. \& Lewis, D. (1970). Br. Poult. Sci. 11, 367.

Harper, A. E., Benevenga, N. J. \& Wohlhueter, R. M. (1970). Physiol. Rev. 50, 428.

Hewitt, D. \& Lewis, D. (1972). Br. Poult. Sci. 13, 465.

Miller, D. S. \& Payne, P. R. (1963). F. theor. Biol. 5, 1398.

Negassi, A. \& Morris, T. R. (1973). Wld's Poult. Sci. F. 29, 285.

Porter, J. W. G. \& Rolls, B. A. (editors) (1973). In Proteins in Human Nutrition. London: Academic Press.

Summers, J. D. \& Fisher, H. (196I). F. Nutr. 75, 435.

Woodham, A. A. (1 968). Br. Poult. Sci. 9, 53. 